\title{
IMPLEMENTASI SISTEM PELAYANAN MITRA PADA PT. PELINDO II (PERSERO) CABANG TANJUNG PRIOK JAKARTA
}

\author{
Anggi Oktaviani \\ Program Studi Teknik Informatika \\ STMIK Nusa Mandiri Jakarta \\ Jl. Damai No. 8 Warung Jati Barat (Margasatwa) Jakarta Selatan \\ anggi.aov@nusamandiri.ac.id \\ Dahlia Sarkawi \\ Program Studi Sekretari \\ ASM BSI Jakarta \\ Jl. Jatiwaringin Raya No. 18, Jakarta Timur \\ dahlia.dls@bsi.ac.id \\ Suhardjono \\ Program Studi Manajemen Informatika \\ AMIK BSI Jakarta \\ JI. R.S. Fatmawati No. 24, Pondok Labu, Jakarta Selatan. \\ suhardjono@bsi.ac.id
}

\begin{abstract}
ABSTRAK
PT. Pelabuhan Indonesia II atau PELINDO II Cabang Tanjung Priok merupakan perusahaan Badan Usaha Milik Negara (BUMN) yang bergerak dibidang kegiatan pelayanan jasa kepelabuhan. Pelayanan kapal dan barang merupakan tugas yang diemban pada lingkungan pelabuhan PT. PELINDO II Cabang Tanjung Priok. Teknologi Informasi sangat dibutuhkan agar kegiatan pelayanan dapat tersaji secara cepat, tepat dan efisien. PT PELINDO II Cabang Tanjung Priok telah menerapkan sistem berbasis Information Commnucation Technology (ICT). Namun tidak demikian pada divisi Uster yang masih menggunakan cara manual sehubungan dengan pelayanan keluhan mitra/ customer terhadap kegiatan operasional kapal dan barang seperti banyaknya kendala yang sangat mengganggu kegiatan operasional dan keluhan tersebut diketahui masih hanya sebatas level Top Manager. Dan dengan adanya sistem pelayanan tersebut, maka perusahaan terutama karyawan yang berhadapan langsung dilapangan akan mengetahui berbagai keluhan yang dirasakan mitra/customer selama menjadi pengguna jasa yang ada dilingkungan PT. PELINDO I/ Cabang Tanjung Priok.
\end{abstract}

\section{ABSTRACT}

PT. Pelabuhan Indonesia II or PELINDO II Tanjung Priok Branch is a State-Owned Enterprises engaged in port service activities. The service of ships and goods is a task carried on the environment of the port of PT. PELINDO II Tanjung Priok Branch. Information Technology is needed for service activities can be presented quicklu, presely and efficiently. PT. PELINDO II Tanjung Priok Branch has implemented Information Communication Technology (ICT) based system. However, the uster division is still using masnual methods in relation to customer complaints service to ship operational activities and good such as the many obstacles they are very disturbing the operational activities and complaints are known still onlu limited to the TOP Manager Level. And with the existence of the service system, then the company, especially employees who are facing directly in the field will know the various complaints felt by partner/ customer during the service users who are environment PT. PELINDO II Tanjung Priok Branch

Kata Kunci: pelayanan, teknologi, ICT, jasa, sistem

\section{PENDAHULUAN}

Pelabuhan adalah tempat yang berdiri dar daratan dan perairan disekitarnya dengan batasbatas tertentu sebagai tempat kegiatan pemerintahan dan kegiatan ekonomi yang dipergunakan sebagai tempat kapal bersandar berlabuh, naik turun penumpang dan bongkar muat barang yang dilengkapi dengan fasilitas keselamatan pelayaran dan kegiatan penunjang pelabuhan serta sebagai tempat perpindahan intra dan antar mode transportasi. Oleh karena itu perusahaan pelabuhan menjadi salah satu faktor penting dalam menjalankan perekonomian Negara. Dari segi aspek teknologi informasi, PT. PELINDO II (Persero) Cabang Tanjung Priok telah menerapkan sistem layanan berbasis Information Commnucation Technology (ICT). Namun tidak demikian pada divisi Uster yang sehubungan dengan keluhan Mitra atau Customer. Karena pada saat ini masih menggunakan sistem manual dan masih banyak sekali permasalahan yang berkaitan dengan keluhan terebut. Adapun permasalahan yang ada saat ini adalah sebagai berikut: 
1. Keterbatasan pengetahuan pekerja operasional terhadap berbagai keluhan yang dirasakan mitra atau customer yang terjadi pada kegiatan operasional dan berdampak pada kerterlambatan jalannya kegiatan operasional itu sendiri.

2. Keterlambatan penanganan keluhan yang sudah diajukan oleh customer sebelumnya dikarenakan dokumen dokumen yang berisi tentang keluhan tersebut masih dijalankan secara manual yaitu dengan menggunakan surat resmi yang hanya diketahui sebatas level Top Manager dan sangat membutuhkan waktu untuk sampai pada tahap penanganannya.

Untuk menerapkan sistem ICT yang lebih maju, maka sistem yang ada saat ini perlu dikembangkan lebih lanjut agar permasalahan yang ada saat ini dapat teratasi terutama dari segi efisiensi waktu yang berkaitan dengan kegiatan operasional dilapangan.

\section{LANDASAN TEORI}

\subsection{Sistem}

"Suatu sistem adalah suatu jaringan kerja dari prosedur-prosedur yang saling berhubungan, berkumpul bersama-sama untuk melakukan suatu kegiatan atau untuk menyelesaikan suatu sasaran yang tertentu".( Jerry Fitz Gerald dan Werren D Stalling Jr., 1981) Pengertian sistem di artikan suatu susunan yang teratur dari kegiatan yang berhubungan satu sama lainya serta prosedurnya yang berkaitan untuk melaksanakan dan memudahkan pelaksanaan kegiatan dan suatu organisasi.

Menyatakan bahwa sistem adalah suatu kesatuan yang terdiri dari interaksi subsistem yang berusaha untuk mencapai tujuan yang sama. Dari definisi-definisi sistem tersebut diatas dapat dikatakan bahwa sistem terdiri dari unsurunsur atau elemen tersebut mempunyai bentuk yang tertentu dan saling mempengaruhi untuk mencapai satu atau beberapa maksud secara bersama-sama berkeinginan untuk mencapai tujuan yang sama pula. Dapat pula dikatakan bahwa suatu sistem terdiri dari struktur dan proses. Struktur merupakan unsur-unsur secara terintergritas membentuk sistem tersebut. Sedangkan proses merupakan penjelasan prosedur atau tata aturan kerja dari suatu sistem untuk mencapai tujuan tertentu. Agar suatu sistem dapat bekerja secara efisien dan efektif maka setiap struktur dan proses tersebut harus saling berkaitan antara satu dengan yang lainya. (Stephen A. Mascove dan Mark G Simkin, 1984)

\subsection{Karakteristik Sistem}

Model umum sebuah sistem adalah input, proses dan output. Hal ini merupakan konsep sebuah sistem dapat mempuyai beberapa masukan dan keluaran. Suatu sistem mempuyai karakteristik atau sifat-sifat tertentu, yaitu terdiri dari :
1. Komponen (component)

Suatu sistem terdiri dari sejumlah komponen yang saling berinteraksi membentuk satu kesatuan.

2. Batasan Sistem (Boundary)

Merupakan daerah yang membatasi antara satu sistem dengan sistem yang lainya atau dengan lingkungan luarnya.

3. Lingkungan Luar (Enviroment)

Enviroment dari suatu sistem adalah apaoun diluar batas sistem yang mempengaruhi operasi sistem, lingkungan luar sistem dapat bersifat menguntungkan dan juga dapat bersifat merugikan sistem tersebut.

4. Penghubung Sistem (Interface)

Penghubung atau interface merupakan media penghubung antara satu subsistem dengan subsitem lainya.

5. Masukan Sistem (Input)

Adalah energi yang dimasukan ke dalam sistem. Masukan dapat berupa masukan perwatan (Maintenance Input) dan masukan sinyal (Signal Input).

6. Keluaran Sistem (Output)

Keluaran (Output) adalah hasil dari energy yang diolah dan diklasifikasikan menjadi keluaran yang berguna. Keluaran dapat masukan untuk subsitem yang lain atau kepada supra sistem.

7. Pengolah Sistem

Suatu sistem dapat mempunyai suatu bagian pengolah yang akan merubah masukan menjadi keluaran.

8. Sasaran Sistem (Objective)

Suatu sistem pasti mempunyai tujuan (goal) atau sasaran (objective), kalau suatu sistem tidak mempunyai sasaran maka operasi sistem tidak akan ada gunanya

\subsection{Pengertian Informasi}

Telah diketahui bahwa informasi merupakan hal yang sangat penting bagi manajemen didalam pengambilan keputusan. Informasi menunjukan hasil dari pengolahan data yang telah diorganisasikan dan berguna bagi orang yang menerimanya. "Sistem Informasi adalah suatu suatu sistem didalam organisasi yang mempertemukan kebutuhan pengolahan transaksi harian, mendukung operasi, bersifat manajerial dan kegiatan strategi dari luar organisasi dan menyediakan pihak luar tertentu dengan pihak luar tertentu. Dengan laporan yang diperlukan. Dari pengertian informasi di atas dapat ditarik kesimpulan bahwa informasi merupakan hasil akhir dari data yang telah diproses pada suatu sistem sehingga menjadi bentuk yang telah berguna bagi yang menerimanya untuk pengambilan keputusan.

Banyak referensi yang mengatakan bahwa Sistem adalah suatu group dari elemen-elemen baik berbentuk fisik maupun bukan fisik yang menunjukkan suatu kumpulan saling berhubungan diantaranya dan berinterkasi bersama-sama menuju satu atau lebih tujuan sasaran akhir dari sistem (M.J Alexander, 1982). 
Sedangkan (Robert.A.Letch, 2012) "Sistem adalah kumpulan dan elemen-elemen (orang, perangkat keras, Informasi dan lain-lain) diorganisasikan untuk mencapai satu tujuan tertentu.

Sistem informasi terdiri dari komponenkomponen yang tersebut dengan blok bangunan (Building Blok) yang terdiri dari :

\section{a. Blok Masukan}

Input mewakili data yang masuk kedalam sistem informasi, input disini termasuk metode dan media untuk menangkap data yang akan dimasukan, berupa dokumen-dokumen dasar

\section{b. Blok Model}

Blok ini terdiri dari kombinasi prosedur, logika dan matematika yang akan memanipulasi data input dan data yang tersimpan dibasis data dengan cara yang sudah tertentu untuk menghasilkan keluaran yang diinginkan.

\section{c. Blok Keluaran}

Produk dari keluaran sistem informasi adalah keluaran yang merupakan informasi yang berkualitas dan komunikasi yang berguna untuk semua tingkat manajemen serta semua pemakai sistem.

\section{d. Blok Teknologi}

Teknologi merupakan "tool box" dalam sistem informasi, teknologi digunakan untuk menerima input, menjalakan model, menyimpan dan mengakses data, menghasilkan dan mengirimkan keluaran dan membentuk pengandalian dari sistem secara keseluruhan. Teknologi terdiri dari tiga bagian utama yaitu tekhnisi (brainware), perangkat lunak (software) dan perangkat keras (hardware).

\section{e. Blok Basis Data}

Basis data (databases) merupakan kumpulan data yang saling berkaitan dan berhubungan satu dengan yang lainya, tersimpan diperangkat keras komputer digunakan perangkat untuk memanipulasinkan. Basis data diakses atau dimanipulasi dengan menggunakan perangkat lunak paket yang disebut dengan DBMS (Database Management System).

\section{f. Blok Kendali}

Banyak hal yang dapat merusak sistem informasi, seperti bencana alam, api, temperature, air, debu, kecurangan-kecurangan, kegagalan-kegagalan sistem itu sendiri, ketidak efesienan, sabotase dan lain sebagainya. Beberapa pengandalian perlu dirancang dan diterapkan untuk meyakinkan bahwa hal-hal yang dapat merusak sistem dapat dicegah ataupun bila terlanjur terjadi kesalahankesalahan dapat langsung cepat diatasi.

\subsection{Pengertian Informasi Manajemen}

Definisi Sistem Informasi Manajemen menurut Wilkinson. Bahwa sistem informasi manajemen adalah: "Suatu Kerangka yang menjadi alat-alat penghubung bagi sumber daya yang terkoordinasi guna mengumpulkan, memperoses, mengendalikan dan informasi yang disampaikan melalui jaringan komunikasi ke berbagai pemakian menuju satu tujuan atau lebih.

Pendapat lain juga dikemukakan (Bary E Cushing, 1981), menurutnya Sistem Informasi Manajemn adalah "Suatu kumpulan manusia dan sumber modal didalam suatu organisasi yang bertanggung jawab untuk mengumpulkan dan mengolah data dalam menghasilkan informasi yang berguna bagi setiap tingkat manajemen dalam perancangan dan pengendalian aktivitas-aktivitas organisasi.

\subsection{Tools Pendukung Software}

\section{a. Website}

(Sutarman, 2007) menjelaskan bahwa “ website merupakan salah satu sumber daya internet yang berkembang pesat. Informasi web di distribusikan melalui hypertext, yang memungkinkan suatu teks pendek menjadi acuan untuk membuka dokumen yang lain". Website atau situs juga menampilkan informasi data teks, data gambar diam atau gabungan dari semuanya, baik yang bersifat statis maupun dinamis yang membentuk suatu rangkaian bangunan yang paling berkait dimana masing-masing dihubungkan dengan jaringan halaman ( hyperlink).

\section{b. Web Browser}

(Limantara, 2009) menjelaskan bahwa "Web Browser merupakan aplikasi peerangkat lunak yang memungkinkan pengguna untuk berinteraksi dengan teks, image, vidio, dan informasi lainnya yang berlokasi pada halaman web pada World Wide Web (WWW) atau Local Area Network (LAN)". Contohnya seperti Mozilla Firefox dan Internet Explorer

\section{c. Web Server}

(Pratama, 2014) menjelaskan bahwa "Web server adalah Perangkat lunak yang dijalankan di sistem operasi pada komputer server maupun desktop, yang berfungsi untuk menerima permintaan dalam bentuk protokol misalkan HTTPS (Hypertext Transfer Protokol Secure)". Request tersebut kemudian dibalas (reply) dengan cara mengirimkan hasil permintaan tersebut melalui web browser. Protokol sendiri merupakan aturan dan standar baku untuk protes komunikasi, hubungan, dan transfer data antar komputer pada jaringan.

\section{d. Adobe Dreamweaver CS3}

(Hadi, 2008) menjelaskan bahwa Dreamweaver merupakan web editor untuk membuat dan mendesain website dengan mudah dan cepat. Kemampuan dalam membuat website tanpa menuliskan tag-tag HTML satu persatu menjadikan salah satu web editor favorit banyak pengguna.

\section{e. Javascript}

(Winaro,2010) menjelaskan bahwa "Javascipt adalah bahasa pemograman website sederhana yang dikembangkan oleh netscape, bahasa javascript merupakan bahasa client - side artinya pengekskusi kode dilakukan di sisi klien atau browse". Sehingga prosesnya tergantung dari browser yang digunakan. 


\section{f. PHP}

(Winaro,2010) menjelaskan bahwa "PHP Hypertext Prepocessor, yaitu bahasa pemograman web yang apabila dilihat dari cara kerjanya merupakan bahasa pemograman web yang diolah di sisi server atau sering disebut server side scripting".

\section{g. Basis Data}

(Yuhefizar, 2008) Menjelaskan bahwa "Database diartikan sebuah koleksi atau kumpulan data yang saling berhubungan ( Relation ), disusun menurut aturan tertentu secara logis, sehingga menghasilkan informasi".

Secara prinsip, dalam suatu database tercangkup dua komponen penting, yaitu data dan informasi. Data adalah fakta, baik berupa sebuah objek, orang dan lain-lain yang dapat dinyatakan dengan suatu nilai tertentu (angka, simbol, karakter,tertentu). Sedangkan informasi adalah data yabg telah diolah sehingga bernilai guna dan dapat dijadikan bahan dalam pengambil keputusan.Database terbentuk dari beberapa komponen.

\section{h. My Sql}

(Hidayatullah dan Kawistara 2014) menjelaskan bahwa "MySQL adalah salah satu aplikasi DBMS (Database Management system) yang sudah sangat banyak digunakan oleh para pemogram aplikasi web, seperti SQL server, MS Acces dari Microsoft". Kelebihan MySQL yaitu gratis, handal, selalu di- update dan banyak forum yang memfasilitasi para pengguna jika memliki kendala.

\section{i. ERD (Entrerprise Relation Diagram)}

(Pratama, 2014) menjelaskan bahwa "Enterprise Relation Diagram ( $E R D$ )yaitu diagram yang menggambarkan keterkaitan antar tabel dengan field-field di dalamnya pada suatu database sistem, sebuah database memuat minimal sebuah tabel dengan sebuah atau beberapa field(kolom) di dalamnya". Enterprise Relation Diagram ( $E R D$ )

\section{METODOLOGI PENELITIAN}

Metode pengumpulan data penelitian yang penulis gunakan antara lain:

1. Observasi (Observation)

Metode ini mencakup pengumpulan data mengenai sistem pelayanan di PT.Pelindo II

2. Wawancara (Interview)

Metode tanya jawab mengenai semua kegiatan yang berhubungan dengan pelayanan terhadap pengguna jasa atau mitra, dengan supervisor pelaksana bongkar muat yaitu Bapak Rajamin Aman Sitanggang dan staf yang biasa menangani langsung kegiatan bongkar muat di PT. PELINDO II yaitu Bapak Teten Sutendi.

3. Studi Pustaka (Literature)

Penulis juga melakukan studi kepustakaan melalui halaman ebook untuk studi secara online dan melalui perpustakaan untuk studi secara offlinenya yang ada di Akademi
Manajemen Informatika Bina Sarana Informatika maupun perpustakaan lainnya.

Metode penelitian yang diterapkan pada penelitian ini adalah dengan pengembangan metode waterfall. Metode waterfall merupakan model pengembangan sistem informasi yang sistematik dan sekuensial [1]. Metode Waterfall memiliki tahapan-tahapan sebagai berikut [2]:

1) Requirements analysis and definition

Layanan sistem, kendala, dan tujuan ditetapkan oleh hasil konsultasi dengan pengguna yang kemudian didefinisikan secara rinci dan berfungsi sebagai spesifikasi sistem.

2) System and software design

Tahapan perancangan sistem mengalokasikan kebutuhan-kebutuhan sistem baik perangkat keras maupun perangkat lunak dengan membentuk arsitektur sistem secara keseluruhan. Perancangan perangkat lunak melibatkan identifikasi dan penggambaran abstraksi sistem dasar perangkat lunak dan hubungannya.

3) Implementation and unit testing

Pada tahap ini, perancangan perangkat lunak direalisasikan sebagai serangkaian program atau unit program. Pengujian melibatkan verifikasi bahwa setiap unit memenuhi spesifikasinya.

4) Integration and system testing

Unit-unit individu program atau program digabung dan diuji sebagai sebuah sistem lengkap untuk memastikan apakah sesuai dengan kebutuhan perangkat lunak atau tidak. Setelah pengujian, perangkat lunak dapat dikirimkan ke customer.

5) Operation and maintenance

Tahapan ini merupakan tahapan yang paling panjang. Sistem dipasang dan digunakan secara nyata. Maintenance melibatkan pembetulan kesalahan yang tidak ditemukan pada tahapan-tahapan sebelumnya, meningkatkan implementasi dari unit sistem, dan meningkatkan layanan sistem sebagai kebutuhan baru.

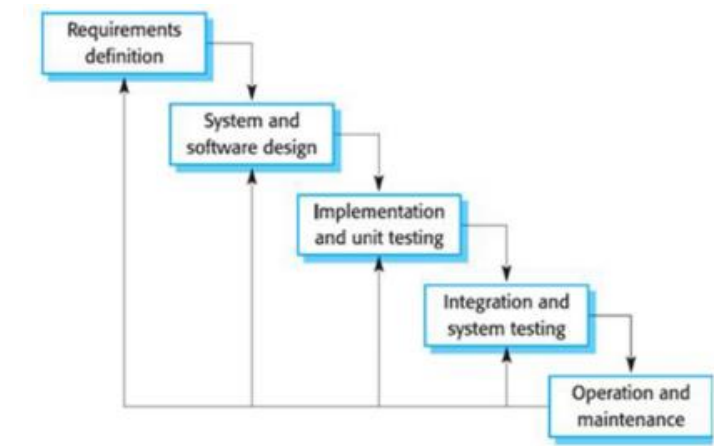

Sumber: Sommerville (2011)

Gambar 1. Model Waterfall.

\section{HASIL DAN ANALISA}

4.1 Tinjauan Perusahaan

Pelabuhan memiliki peranan penting dalam pertumbuhan ekonomi suatu Negara. Salah satu 
contohnya yaitu dengan proyek pendulum nusantara yang dilakukan oleh PT. Pelabuhan Indonesia II (Persero) sebagai wujud dukungan program pemerintah yang tercantum dalam Masterplan Percepatan dan Perluasan Pembangunan Ekonomi Indonesia (MP3EI) untuk dapat mempercepat realisasi perluasan pembangunan ekonomi dan pemerataan kemakmuran dikalangan masyarakat Indonesia. Proyek pendulum nusantara merupakan jalur yang menghubungkan pelabuhan-pelabuhan strategis di Indonesia dari timur ke barat. Pelabuhan-pelabuhan tersebut akan ditingkatkan baik fasilitas maupun infrastruktunya untuk dapat melayani kapal dengan ukuran relatif besar sehingga dapat menurunkan biaya logistic nasional dan mendorong pemerataan pertumbuhan ekonomi di seluruh Indonesia.

\subsection{Sejarah Perusahaan}

Pengelolaan pelabuhan umum dilakukan oleh Perusahaan Negara (PN) Pelabuhan I sampai dengan IV berdasarkan undang-undang nomer 19 prp tahun 1960. Aspek komersial dari pengelolaan pelabuhan tetap dilakukan oleh Perusahaan Negara Pelabuhan, tetapi kegiatan operasional pelabuhan dikoordinasikan oleh lembaga pemerintah yang disebut Port Authority. Pengelolaan pelabuhan masing-masing pelabuhan umum dilakukan oleh Badan Pengusahaan Pelabuhan (BPP) berdasarkan Peraturan Pemerintah Nomer 1 Tahun 1969.

Pengelolaan pelabuhan umum dibedakan menjadi pelabuahn umum yang diusahakan dan pelabuhan umum yang tidak diusahakan. Pengelolaan pelabuhan umum yang diusahakan dilakukan oleh perusahaan umum (PERUM) Pelabuhan, sedangkan pengelolaan pelabuhan umum yang tidak diusahakan dilakukan oleh Unit Pelaksana Teknis Direktorat Jendral Perhubungan Laut sebagaimana diatur dalam Peraturan Pemerintah Nomer 11 Tahun 1983. PERUM Pelabuhan II merupakan salah satu dari empat PERUM pelabuhan yang mengelola pelabuhanpelabuhan yang diusahakan dan dibentuk berdasarkan Peraturan Pemerintah Nomer 15 Tahun 198.

Perubahan status PERUM Pelabuhan II menjadi PT. Pelabuhan Indonesia II (Persero) sesuai Peraturan Pemerintah Nomer 57, tanggal 19 Oktober 1991 dan dikukuhkan dengan Akta Notaris Imas Fatimah Sarjana Hukum dijakarta pada tanggal 1 Desember 1992. Peningkatan status perusahaan dari PERUM Pelabuhan II menjadi PT. Pelabuhan Indonesia II (Persero) merupakan suatu kepercayaan dari Pemerintah, didasarkan pada pertimbangan keberhasilan manajeman meningkatkan pengelolaan pelabuhan-pelabuhan yang diusahakan selama ini.

PT. Pelabuhan Indonesia II (Persero) atau Pelindo II meluncurkan identitas korporasi baru berupa logo IPC. Identitas korporasi baru ini mengukuhkan semangat baru PT. Pelabuhan Indonesia II (Persero) dalam bertransformasi menjadi IPC, perusahaan penyedia layanan kepelabuhanan di Indonesia yang lebih effisien dan modern dalam berbagai aspek operasinya guna mencapi tujuan menjadi operator pelabuhan kelas dunia. Semangat transformasi tersebut diterapkan kedalam seluruh aktivitas perusahaan, baik pada aspek strategis manajemen, operasional maupun peningkatan sumber daya manusia yang secara komprehensif, gesit dan fleksibel dengan berpegangan pada prinsip memajukan perdagangan, memajukan Indonesia. Energizing Trade, Energizing Indonesia.

Adapun Visi dan Misi PT. Pelabuhan Indoensia II (Persero) sebagai berikut:

\section{VISI}

Menjadi Pengelola Pelabuhan Kelas Dunia yang Unggul dalam Operasional dan Pelayanan.

\section{MISI}

\section{Pelanggan dan Mitra}

Menyediakan, membangun dan mengoperasikan pelayanan kepelabuhanan dan logistik secara terintegrasi berkualitas dan handal untuk memenuhi kepuasana pelanggan dan mitra.

\section{Karyawan}

Menciptakan lingkungan yang nyaman bagi karyawan, mewujudkan insan perusahaan yang fokus pada pelanggan, berintegrasi, bangga kepada perusahaan dan budayanya serta memberikan kesejahteraan dan kepuasan kepada karyawan.

\section{Pemegang Saham}

Memaksimalkan nilai perusahaan bagi pemegang saham dan meningkatkan kesehatan secara professional dengan memenuhi aspek-aspek tata kelola perusahaan yang baik

\section{Masyarakat dan Negara}

Menjamin kelancaran dan keamanan arus kapal dan barang untuk mewujudkan efisiensi biaya logistic dalam rangka memacu peetumbuhan ekonomi nasional yang berdampak pada peningkatan kesejahteraan masyarakat.

\subsection{Struktur Organisasi}

Untuk mengolah perusahaan dengan baik dan optimal, terutama terhadap sumber daya manusia, perusahaan menerapkan manajemen yang dituangkan dalam bentuk struktur organisasi merupakan sarana yang sangat penting untuk menjalankan fungsinya. 


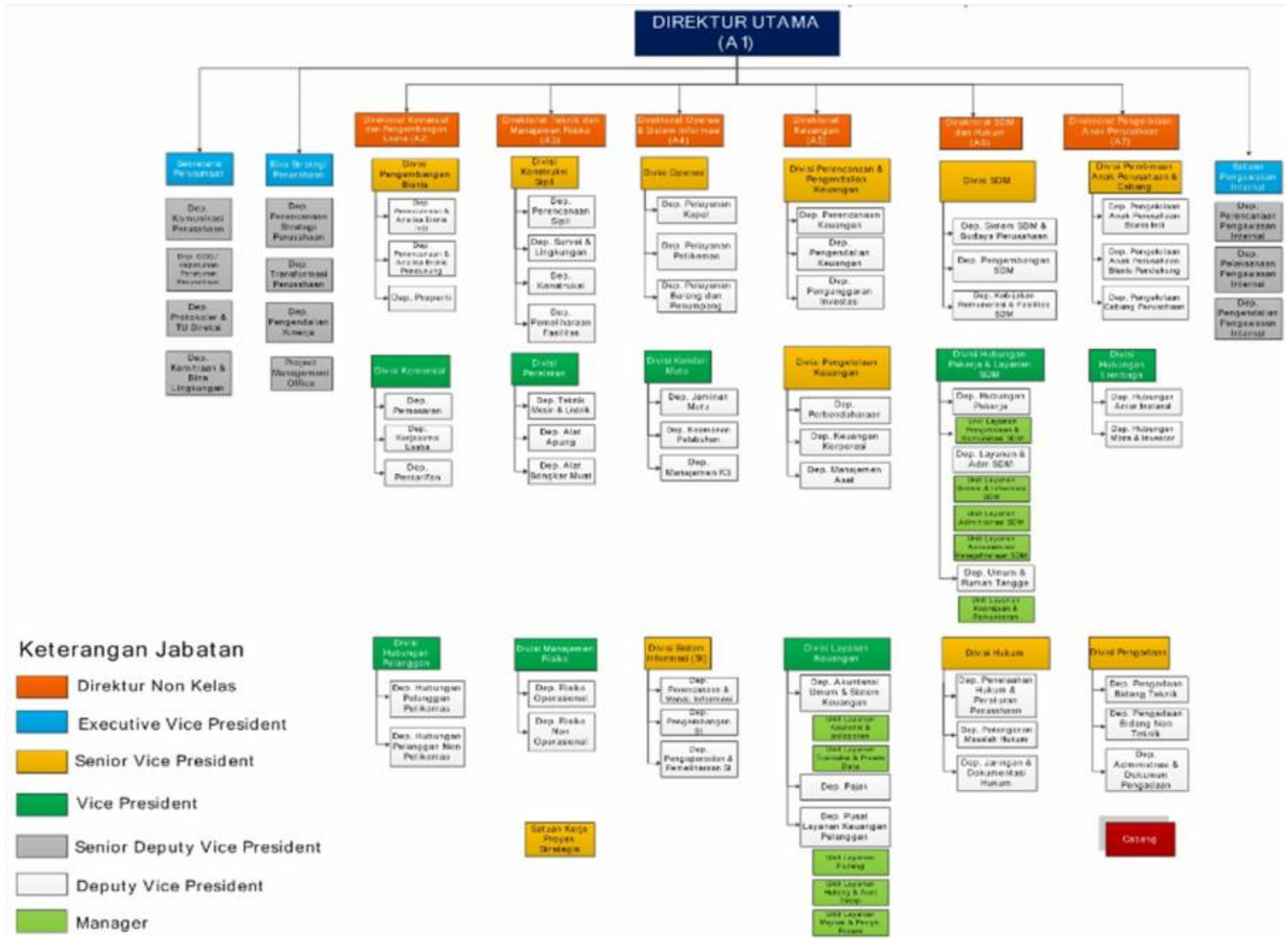

Gambar 2. Struktur Organisasi PT. Pelindo II berikut:

Fungsi dari tiap-tiap bagian adalah sebagai

1. Direksi

a. Bertanggung jawab atas jalanya

b. Membuat rencana kerja bagi perusahaan sebagai dasar kebijakan dalam mengkordinasi jalanya perusahaan

c. Bertanggung jawab atas segala aktivitas yang terjadi baik didalam maupun diluar perusahaan.

d. Aktivitas berhubungan dengan konsumen dan pihak ketiga yang berhubungan dengan kegiatan keuangan perusahaan.

2. Sekretaris Perusahaan

a. Komunikasi Perusahaan

b. Kepatuhan Peraturan Perusahaan

c. Protokoler TU \& Direksi

d. Kemitraan \& Bina Lingkungan

3. Strategi Perusahaan

a. Perancangan Strategi Perusahaan

b. Transformasi Perusahaan

c. Pengendalian Kinerja

d. Manajeman Office

4. Satuan Pengawasan Lingkungan

a. Perencanaan Pengawasan Lingkungan

b. Pelaksanaan Pengawasan Internal

c. Pengendalian Pengawasan Internal
5. Direktorat Komersial dan Pengembangan Usaha

a. Divisi Pengembangan Bisnis

1. Perencanaan dan Analisis Bisnis Inti

2. Perencanaan dan Analisis Bisnis Pendukung

3. Properti

b. Divisi Komersial

1. Pemasaran

2. Kerjasama usaha

3. Pentarifan

6. Direktorat Teknik dan Manajeman Risiko

a. Divisi Kontruksi Sipil

1. Perencanaan Sipil

2. Survei dan Lingkungan

3. Konstruksi

4. Pemeliharaan Fasilitas

b. Divisi Peralatan

1. Teknik Mesin dan Listrik

2. Alat Apung

3. Alat Bongkar Muat

7. Direktorat Operasi \& Sistem Informasi

a. Divisi Operasi

1. Pelayanan Kapal

2. Pelayanan Petikemas

3. Pelayanan Barang dan Penumpang

b. Divisi Mutu dan Kendali

1. Jaminan Mutu

2. Keamanan Pelabuhan

3. Manajeman K3 
8. Direktorat Keuangan

a. Divisi Perencanaan dan Pengendalian

Keuangan

1. Perencanaan Keuangan

2. Pengendalian Keuangan

3. Penganggaran Investasi

b. Divisi Pengelolaan Keuangan

1. Perbendaharaan

2. Keuangan Korperasi

3. Manajeman Aset

9. Direktorat SDM dan Hukum

a. Divisi SDM

1. Sistem SDM dan Budaya Perusahaan

2. Pengembangan SDM

3. Kebijakan Remunerasi \& Fasilitas SDM

b. Divisi Hubungan Pekerja dan Layanan SDM

1. Hubungan Pekerja

2. Layanan Pengelolaan \& Komunikasi SDM

3. Layanan \& Adm SDM

10. Direktorat Pengelolaan Anak Perusahaan

a. Divisi Pembinaan Anak Perusahaan

1. Pengelolaan Anak Perusahaan Bisnis Inti

2. Pengelolaan Anak Perusahaan Bisnis Pendukung

3. Pengelolaan Cabang Pendukung

b. Divisi Hubungan Lembaga

1. Hubungan Antara Instansi

2. Hubungan Mitra dan Investor

\subsection{Prosedur Sistem Berjalan}

Adapun prosedur proses pelayanan kapal dan barang pada PT.Pelabuhan Indonesia II (Persero) adalah sebagai berikut:

a. Prosedur Pelayanan Kapal Sandar

Proses pelayanan kapal mulai dari kedatangan kapal, pemanduan kapal yang akan sandar, proses penambatan kapal hingga kegiatan bongkar muat.

b. Prosedur Pelayanan Bongkar Muat

Setelah prosedur pelayanan kapal sandar telah selesai, maka berjalanlah kegiatan bongkar dan muat barang baik dalam kategori kargo maupun petikemas.

c. Pembuatan Laporan Kegiatan Bongkar Muat Pada prosedur ini, apabila kegiatan bongkar muat telah selesai, maka akan dibuat pula laporan bongkar muat atau biasanya disebut Realisasi Bongkar Muat (RBM).

d. Pembayaran

Dengan timbulnya laporan RBM, maka customer/ mitra akan segera melakukan pembayaran selama kegiatan mulai dari kapal sandar, kegiatan bongkar muat sampai persiapan kapal tolak nanti.

e. Pelayanan Kapal Tolak

Pada saat semua kegiatan telah selesai, maka akan dilakukan persiapan kapal yang akan tolak mulai dari proses penambatan kapal kembali, pemanduan kapal yang akan tolak hingga pelepasan kapal yang sudah tolak.

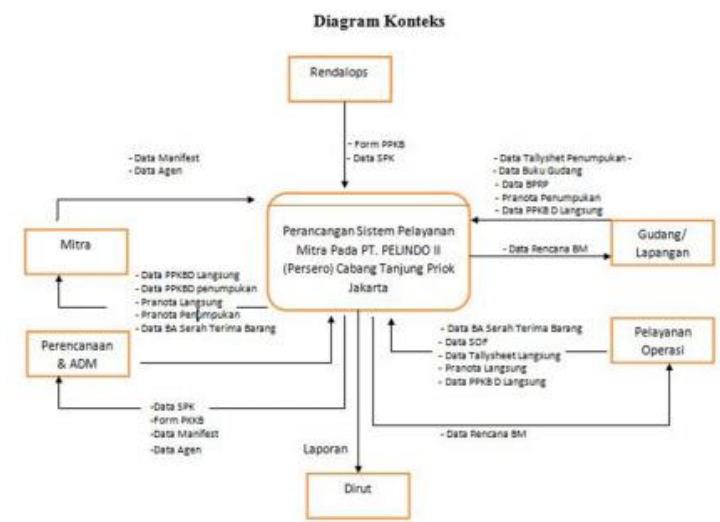

Gambar 3. Diagram Konteks Sistem Berjalan

Keterangan :

PPKB : Permintaan Pelayanan Kapal dan Barang

SPK : Surat Perintah Kerja

BPRP : Bukti Pemakaian Ruang Penumpukan

PPKBD

Langsung: Permintaan Pelayanan Kapal dan Barang

: Berita Acara

RBM : Realisasi Bongkar Muat

SOF : Statement Of Fact

\subsubsection{Permasalahan Pokok}

Sistem pelayanan customer yang ada di PT. PELINDO II (Persero) Cabang Tanjung Priok Jakarta pada dasarnya sudah berjalan dengan baik, namun dengan berbagai permasalahannya yang penulis temui di lapangan.

Adapun permasalahan saat ini sebagai berikut:

1 Dalam pelaksanaannya, sistem pelayanan customer sampai saat ini masih manual, yaitu dengan menggunakan surat tertulis resmi.

2 Hanya diketahui sebatas level TOP Manager.

3 Sangat membutuhkan waktu untuk sampai pada tahap penanganannya.

4 Dalam point ke-3 sering terjadi gangguan terkait kegiatan bongkar muat yang pada dasarnya terus berjalan setiap saat.

\subsubsection{Alternatif Pemecahan Masalah}

Untuk mengatasi masalah tersebut, maka dibutuhkan adanya perbaikan dan perubahan sistem yang sudah ada dengan berdasarkan pada sistem layanan berbasis Information Commnucation Technology (ICT). Yaitu dengan membuat sistem baru untuk bisa digunakan oleh admin yang biasa menangani langsung kegiatan bongkar muat yang ada di lingkungan PT. PELINDO II Cabang Tanjung Priok. Dengan adanya alternative pemecahan masalah ini diharapkan sistem pelayanannya bisa berjalan lebih baik terutama dari segi efisiensi waktu yang sesuai dengan visi dan misi perusahaan.

\subsection{Prosedur Sistem Usulan}

Perusahaan Perseroan (persero) adalah Badan Usaha Milik Negara (BUMN) yang terbentuk perseroan terbatas yang modalnya terbagi dalam saham yang seluruh atau paling sedikit 51\% sahamnya dimiliki oleh pemerintah (atas nama negara) yang tujuan utamanya adalah mengejar 
keuntungan. Dengan semakin berkembangnya teknologi yang sangat cepat dalam menangani aspek kehidupan diperlukan perangkat keras untuk menunjang produktivitas kerja seperti komputer, karena dengan alat ini dapat dibangun suatu sistem komputerisasi. Setelah mempelajari sisten berjalan dan mengetahui permasalahan yang dihadapi PT. PELINDO II (Persero), maka pada bab ini penulis mencoba mengusulkan adanya komputerisasi pada sistem pelayanan customer pada PT. PELINDO II (Persero).

Dalam sistem usulan ini tidak banyak mengalami perubahan dari sistem berjalan yang telah ada. Sistem usulan ini menambahkan beberapa prosedur baru yang penulsi anggap patut untuk diadakan dengan harapan bisa memecahkan permasalahan yang ada demi mencapi tujuan yang hendak dicapai. Dengan adanya sistem baru ini, maka masalah yang sering terjadi dapat ditutupi dengan :

1. Pengembangan sistem pelayanan cutomer yang sudah tidak lagi menggunakan sistem secara manual, melainkan sudah menggunakan sistem komputerisasi.

2. Ketepatan waktu dalam memperoleh data dan informasi yang dibutuhkan.

3. Mengefisiensi waktu dalam hal perhitungan dan informasi lain yang dibutuhkan

Penulis berusaha untuk membantu dan mecapai tujuan dalam pengembangan sistem yang sudah ada agar lebih efisien. Prosedur standar yang berlaku pada PT. PELINDO II (Persero) tetap berlaku dan lebih utama.

Proses pelayanan customer pada sistem usulan sama dengan prosedur sistem berjalan, namun hanya ditambah sedikit perubahanperubahan, mengingat sistem yang berjalan masih menggunakan manual, maka penulis mencoba mengusulkan dengan menggunakan bahasa pemrograman Dreamweaver CS5, adapaun prosedur-prosedur tersebut :

1. Prosedur Penerimaan Laporan Keluhan

Dalam tahap ini, customer sebagai mitra kerja membuat laporan permasalahan yang terjadi dilapangan melalui aplikasi Helpdesk terkait masalah sistem maupun masalah kegiatan operasional.

2. Prosedur Penerimaan SPK

Pada prosedur ini baik administrasi pelayanan sistem maupun pelayanan operasional menerima laporan keluhan customer berkaitan dengan kegiatan operasional yang sedang berjalan berupa pesan masuk atau Inbox melalui email atau account masing-masing administrasi yang kemudian akan diteruskan ke Direksi untuk tahap penanganannya.

3. Prosedur Penanganan Permasalahan Setelah mendapat laporan dari customer terkait permasalahan yang berkaitan dengan kegiatan operasional, sampailah pada tahap penanganan permasalahan tersebut.

4. Prosedur Laporan

Berdasarkan data penanganan yang sudah dijalankan, maka administrasi kegiatan operasional menerima laporan tahap penyelesaian masalah yang kemudian akan diteruskan kembali ke customer.

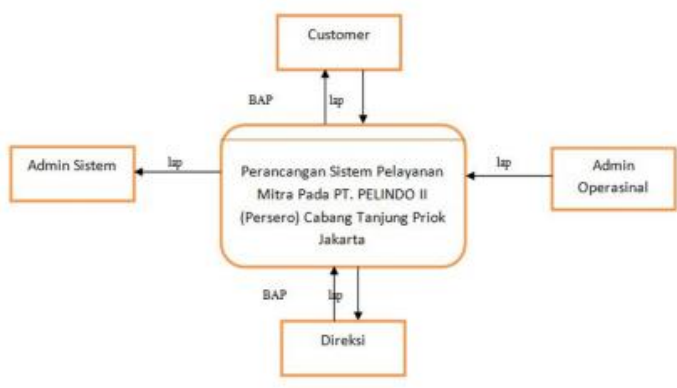

Gambar 4. Diagram Konteks Sistem Usulan

\subsection{Implementasi Web}

4.6.1 ERD

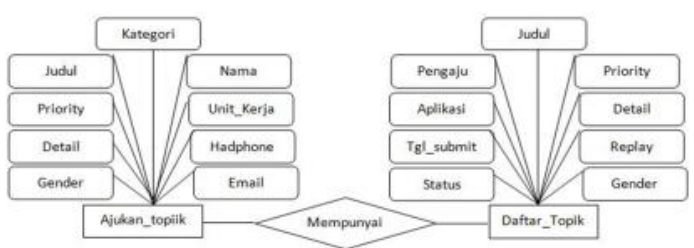

Gambar 5. ERD Usulan

\subsubsection{Struktur Kode}

Pemakaian kode ini berfungsi untuk mengidentifikasi data yang akan digunakan untuk pemrosesan. Adapun tujuan pemakaian kode ini adalah:

1. Kode User

Fungsi : Untuk proses login saat ingin memasuki program aplikasi

Type : Varchar

Panjang : 10 Digit

2. Username

Fungsi : Untuk mengetahui identitas user atau customer

Type : Varchar

Panjang : 10 Digit

\subsubsection{Spesifikasi Web}

Tahap selanjutnya setelah membuat spesifikasi file yang dibutuhkan oleh sistem, kita membuat suatu rancangan yang dibutuhkan sistem usulan. Spesifikasi program merupakan pembahasan mengenai program yang digunakan dalam sistem usulan. Berdasarkan spesifikasi program ini maka diperlukan suatu alat dokumentasi program yang dikenal dengan metode HIPO (Hirarchy of Input Proses Output) yang merupakan bentuk diagram HIPO berdasarkan spesifikasi program yang dibuat: 


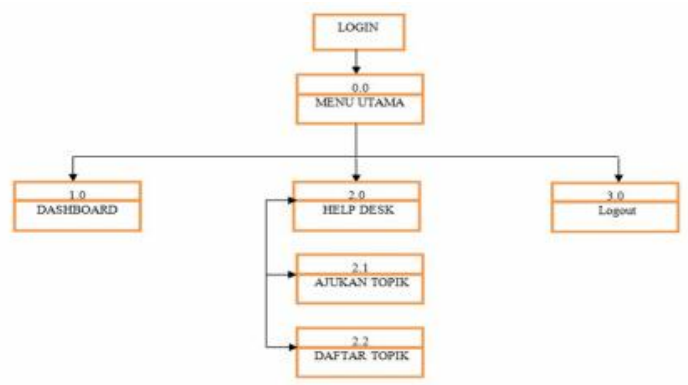

Gambar 6. Diagram Hipo

Spesifikasi program yang diusulkan adalah sebagai berikut:

1. Nama Program : Login

Akronim Program: login.php

Paket Program : Adobe Dreamweaver CS3

Fungsi Program : Untuk membuka aplikasi

Bentuk Format : program yang pertama

Proses Program : 1. Masukan Kode User 2. Masukan Password 3. Login : Untuk masuk kedalam program

2. Nama Program : Dashboard Akronim Program: index.html

Paket Program : Adobe Dreamweaver CS3

Fungsi Program : Tampilan utama aplikasi

Bentuk Format : program

Proses Program : -

3. Nama Program : Ajukan Topik

Akronim Program: form.html

Paket Program : Adobe Dreamweaver CS3

Fungsi Program : Untuk membuat laporan keluhan customer

Bentuk Format : -

Proses Program : 1. Setelah login dan masuk pada menu utama

2. Pilih form ajukan topik pada menu HelpDesk

3. Isi form yang tersedia beserta keluhan yang terjadi di operasional

4. Nama Program : Daftar Topik

Akronim Program: form validation.htm

Paket Program : Adobe Dreamweaver CS3

Fungsi Program : Untuk melihat output daftar topic yang sudah diinput

Bentuk Format :

Proses Program : 1. Setelah login dan masuk pada menu utama

2. Pilih form Daftar Topik

\subsubsection{Rancangan Web}

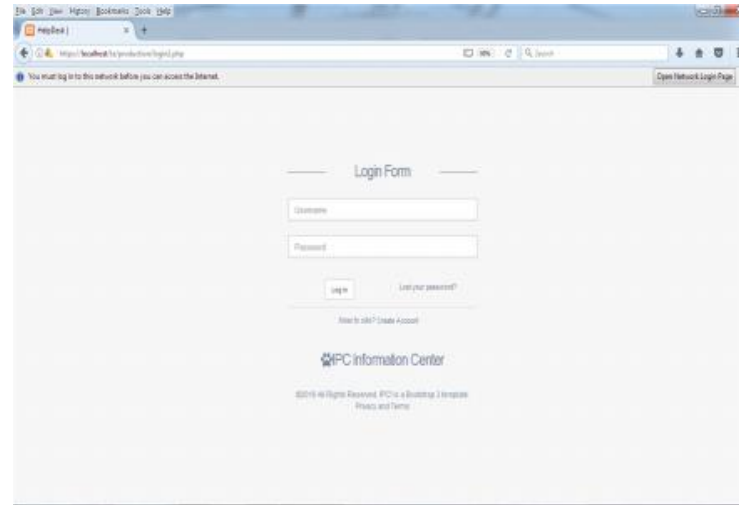

Gambar 7. Tampilan Login

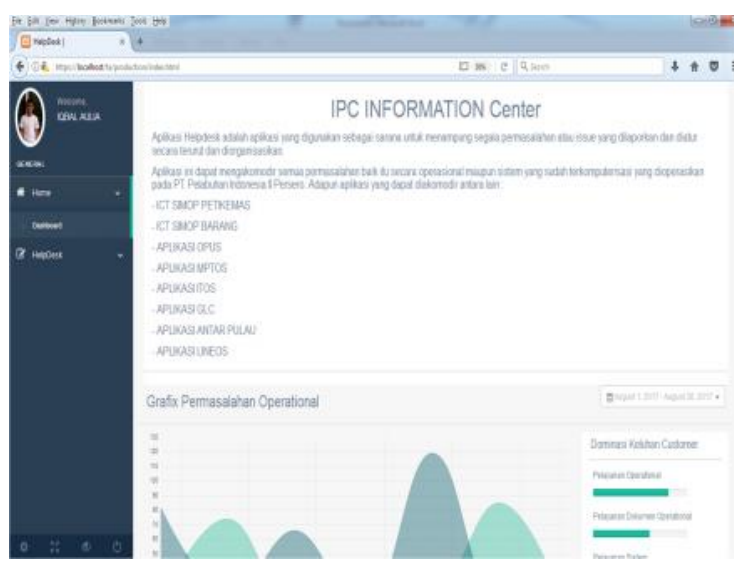

Gambar 8. Tampilan Dashboard

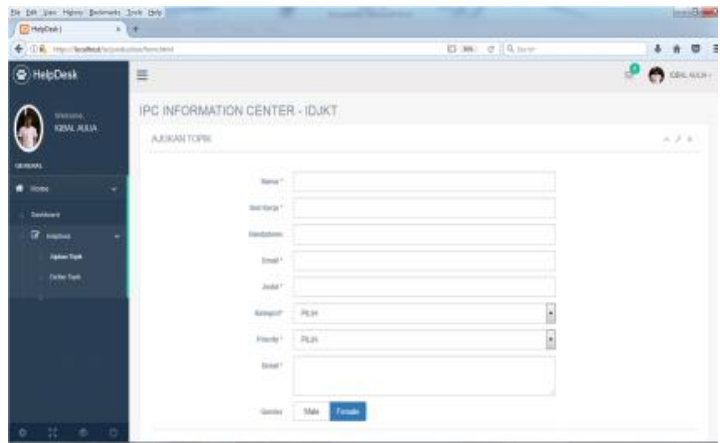

Gambar 9. Tampilan Pengajuan Topik

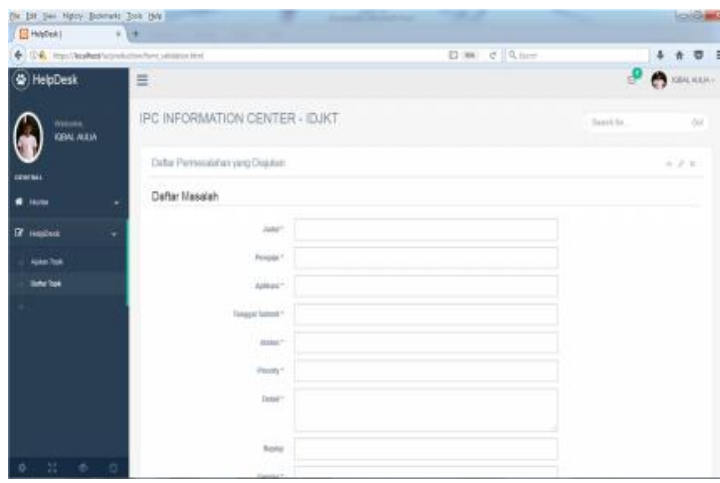

Gambar 10. Tampilan Daftar Topik 


\subsection{5}

Sistem komputer merupakan media yang sangat diperlukan dalam melaksakanakan sistem yang diusulkan, karena setiap sistem yang diusulkan memerlukan suatu program. Program merupakan suatu rancangan yang nantinya digunakan untuk mempermudah penerapan dalam melaksanakan pekerjaan terutama dalam proses pemasukan data. Sehingga dalam menggunakan media komputerisasi dapat meningkatkan kualitas, waktu dan biaya bagi keuntungan perusahaan.

\subsubsection{Perangkat Keras}

Dalam sistem komputerisasi tidak terlepas dari perangkat keras yang akan digunakan, adapun penjelasan mengenai perangkat keras yang digunakan dalam sistem usulan inni adalah:

$\begin{array}{lll}\text { 1. } & \text { Processor } & \text { : Intel Core I3 } \\ \text { 2. } & \text { Memory } & : 512 \mathrm{Mb} \\ \text { 3. } & \text { Harddisk } & : 500 \mathrm{~GB} \\ \text { 4. } & \text { Monitor } & : \text { LCD } \\ \text { 5. } & \text { Keyboard } & : 104 \text { Key } \\ \text { 6. } & \text { Printer } & \text { : Inkjet atau Deskjet } \\ \text { 7. } & \text { Mouse } & \text { : Optik }\end{array}$

\subsubsection{Perangkat Lunak}

Perangkat lunak yang dipakai dalam sistem usulan berupa program-program yang nantinya dapat memberikan kemudahan dalam pengolahan data. Adapun perngkat lunak yang penulias usulkan ini adalah:
1. Sistem operasi
: Microsoft Windows 7
2. Paket Program
: Adobe Dreamweaver CS3
3. Database : PhpMyAdmin

\subsection{Jadwal Implementasi}

Penerapan sistem pelayanan customer pada PT. PELINDO II (Persero) yang diajukan penulis mempunyai tahapan-tahapan sebagai berikut:

1. Penyiapan data awal

Untuk mengetahui penyiapan data awal dapat dilihat dari criteria dibawah ini:

a. Jumlah data yang ada

b. Data-data apa saja yang dikumpulkan

2. Pembuatan atau test program

Pembuatan program dalam sistem usulan dilakukan dengan tujuan menghasilkan program yang dapat digunakan untuk mengolah semua data yang ada dan kumpulkan pada file database. Program yang dibuat haruslah program yang benar-benar mampu memenuhi keinginan penulis yaitu yang nantinya dapat diandalkan pada saat sistem dijalankan dan terjamin bebas dari kesalahan.

3. Pembuatan buku petunjuk

Pembuatan buku petunjuk dimaksudkan untuk membantu dalam menoperasikan sistem yang diusulkan dan pengguna atau pemakai dapat mempelajari dari buku petunjuk ini, baik mengenai data awal, pengadaan training dan lain-lain.

4. Training

Training dimaksudkan unutk melatih para user dalam menggunakan sistem yang diusulkan penulis serta melihat kemampuan dari personel yang terlihat, apakah user telah menguasai paket program yang digunakan pada sistem yang diusulkan.

5. Test sistem

Pembangunan sistem yang diusulkan penulis untuk melakukan uji coba terhadap sistem yang diusulkan secara keseluruhan agar dapat diketahui apakah sistem tersebut layak atau tidak menggantikan sistem yang lama.

6. Peralihan sistem

Kegiatan ini bertujuan untuk meletakan sistem yang baru supaya siap untuk dapat digunakan. Peralihan ini dilakukan secara bertahap untuk menghindari adanya resiko kegagalan sistem baru.

7. Operasional dan evaluasi

Operasi dan evaluasi bertujuan untuk mengoperasikan sistem baru secara penuh setelah masa peralihan berakhir. Selama berlangsungnya sistem baru maka perlu dilakukan evaluasi untuk mengetahui kekurangan-kekurangan dari sistem tersebut agar pembangunan sistem selanjutnya dapat diperbaiki.

\section{KESIMPULAN DAN SARAN}

\subsection{Kesimpulan}

Berdasarkan uraian pembahasan yang penulis lakukan pada PT. PELINDO II (Persero) mengenai sistem pelayanan customer, dapat disimpulkan sebagai berikut:

1. PT. PELINDO II (Persero) Jakarta adalah perusahaan Badan Usaha Milik Negara (BUMN) yang bergerak dibidang jasa kepelabuhanan. Beberapa jeni pekerjaan yang telah dikerjakan oleh PT. PELINDO II (Persero) antara lain : Pelayanan kapal Penumpang, pelayanan penggunaan gudanggudang dan lapangan penumpukan barang, pelayanan jasa bongkar muat barang dan lainlain.

2. Pada dasarnya sistem pelayanan customer pada PT. PELINDO II (Persero) sudah baik, namun dalam penggunaannya masih menggunakan cara manual sehingga sangat membutuhkan waktu untuk sampai pada tahap penanganannya

3. Dengan adanya sistem komputerisasi diharapkan dapat mengefisiensi waktu dalam proses penanganannya.

4. Komputerisasi sebagai alternatif dari permasalahan yang terjadi dan diharapkan dapat mengalami perubahan yang signifikan demi menerapkan sistem layanan berbasis Information Commnucation Technology (ICT) yang lebih maju.

\subsection{Saran}

Penulis mempunyai saran yang dapat dipakai atau digunakan PT. PELINDO II (Persero) Jakarta diantaranya:

1. Pengguna komputer yang menjalankan sistem tersebut diupayakan mampu menguasai dasar-dasar pendidikan komputer. 
2. Perlu adanya kerjasama antara pihak-pihak terkait dalam menjalankan sistem ini.

3. Diadakan pemeliharaan komputer dan aplikasi-aplikasi yang digunakan secara berkala sehingga kesalahan dapat diketahui secepat mungkin.

\section{DAFTAR PUSTAKA}

Cushing, Barry E and Romney. (1994). Accounting Information System sixth edition. United State of America: Addision-Wesley Publishing Company

Hadi, Mulya (2008). 7 Jam Belajar Interaktif Dreamweaver CS3 Untuk Orang Awam. Palembang: Maxikom.

Jauhari Khairul Kawistara, Priyanto Hidayatullah. 2015. Pemrograman Web. Bandung: Penerbit Informatika

Jerry FitzGerald, Andra F. FitzGerald, Warren D. Stalling. Jr (1981), Fundamental of System Analysis, John Willey \& Sons, New York

Limantara, Hans S. (2009). Jelajah Dunia Maya dengan Cepat dan Mudah. Jakarta : PT Elex Media Komputindo

M.J,Alexander (1982). Information System Analysis: Theory and Aplication.

Pratama, I Putu Agus Eka.(2014.) Sistem Informasi dan Implementasinya. Bandung: Informatika Bandung.
Robert A. Letch dan K.Roscoe Davis. (1983), analisis dan Desain Sistem Informasi, Yogyakarta

Wilkinson, J.M., \& Ahern N.R.,(2012). Buku Saku Diagnosis Keperawatan Diagnosa NANDA Intervensi NIC Kriteria Hasil NOC Edisi kesembilan. Jakarta: EGC.

Stephen A.Mascove dan Mark G . Simkin,(1984) Accounting Information System Concepts and Practice for Effective Decision Making, New York: John Wiley and Sons, Second edition, 1984, chapter 1

Sutarman. Membangun Aplikasi Web dengan PHP dan Mysql. Yogyakarta: Graha IImu. 2007.

Winarno, Edi (2010). Pemograman Web Berbasis HTML, PHP, Javascrip. Jakarta: PT Elex Media Komputindo.

Yuhefizar (2008). 10 Jam Menguasai Komputer. Jakarta: PT Elex Media Komputer. 